\title{
Supremasi Hukum dan Demokrasi
}

\author{
Bambang Sugiono \\ Ahmad Husni M.D.
}

\begin{abstract}
The govemment administration laid upon the principle of people's sovereignty is absolutely in need of the enforcement of law supremacy as well as the clear democracy mechanism. The enforcement of law supremacy itself depends on the visibility and the accuracy of the regulation of law and legislation for govemment, representative, and judicial institutions, and the assurance of law protection for individuals (citizens) against the behavior of authority and social action which contradict with the noms of lawas well. In undertaking the enforcement of law supremacy dan democracy, the cultural aspect must be put in line with the quality of substance one. This effort is greatly needed in arranging conflicts so that the maturation of democracy through law enforcement can be consistent and fair.
\end{abstract}

\section{Pendahuluan.}

Supremasi hukum merupakan prasyarat mutlak bagi penyelenggaraan kehidupan kenegaraan berdasarkan kedaulatan rakyat. Supremasi hukum berarti adanya jaminan konstitusional bahwa pelaksanaan dan penegakan hukum dalam proses politik yang dijalankan oleh kekuasaan eksekutif, legislatif

dan yudikatif, akan selalu bertumpu pada kewenangan yang ditentukan olẹh hukum.' Dengan demikian, wewenang berfungsi mendasari pelaksanaan kekuasaan yang sah. $^{2}$ Kekuasaan yang sah dalam penyelenggaraan pemerintahan yang demokratis, adalah jaminan terwujudnya

'Abdul Gani. dalam Padmo Wahjono. 1985. Masalah Ketatanegaraan Indonesia Dewasa Ini. Ghalia Indonesia. HIm.157 ...Menurut teori hukum tentang negara, kekuasaan negara adalah kekuasaan hukum, karenanya validitas kekuasaan hanya ditentukan oleh hukum.

"Bernard Lonergan. "Dialectic of Authority". dalam Frederick J. Adelmann. Authority. Martinus Nijhof. 1984. The Hague.. Hilm.124. ...authority is legitimate power (wewenang adalah kekuasaan yang sah). 
hubungan hukum yang seimbang antara kedaulatan rakyat dengan kekuasaan pemerintahan, berdasarkan asas negara hukum (rechtsstaat), ${ }^{3}$ asas demokrasi dan asas instrumental. ${ }^{4}$

\section{Elemen-elemen Jaminan Supremasi Hukum}

Empat elemen penting dalam negara hukum (rechtsstaat), yang menjadi ciri tegaknya supremsi hukum mencakup, adanya: (i) jaminan bahwa pemerintah dalam menjalankan kekuasaannya selalu dilaksanakan atas dasar hukum dan peraturan penundang-undangan, (ii) jaminan perlindungan hukum terhadap hak-hak dasar (fundamental rights), (iii) pembagian kekuasaan negara yang jelas, adil dan konsisten, serta (iv) perlindungan hukum dari badan-badan peradilan terhadap tindak pemerintahan.

\section{Pemerintahan Menurut Hukum (rechtsmatigheid van bestuur)}

Prinsip pemerintahan berdasarkan atas hukum adalah elemen universal dari konsep negara hukum, tipe apapun negara hukum yang dianut oleh suatu negara. Prinsip tersebut tidak dapat diartikan sebagai pemerintah berkewajiban melaksanakan Undang-undang saja atau prinsip legalitas (wetmatigheid van bestuur). Kendatipun hal tersebut juga menjadi bagian dari jaminan pelaksanaan prinsip persamaan di hadapan hukum dan prinsip kepastian hukum. Negara-negara di dunia dalam realitasnya pemerintahan memang tidak semata-mata menjalankan Undangundang, sebab kekuasaan pemerintahan merupakan kekuasaan yang bersifat aktif. Dengan konsep ini, maka kekuasaan pemerintahan tidak saja sekedar melaksanakan kewenangan terikat, akan tetapi juga merupakan suatu kekuasaan dalam melaksanakan kewenangan bebas (vri) bestuur, freies ermessen, discretionary power).

Kekuasaan yang bertumpu pada kewenangan bebas pada dasarnya terdiri atas kewenangan untuk memutus secara mandiri dan kewenangan interpretasi terhadap norma-norma tersamar (vage normen). Terhadap kekuasaan bebas, maka prinsip legalitas tidaklah memadai. Namun demikian kekuasaan bebas tidaklah dimaksudkan

3Negara Hukum, bertumpu pada 2 konsep, yaitu: (1) konsep negara hukum (rechtsstaat) berasal dan berlaku di sebagian besar negara eropa daratan, dengan elemen-elemen: prinsip legalitas, perlindungan atas hak dasar, pembagian kekuasaan dalam penyelenggaraan pemerintahan negara, pemerintahan berdasarkan undang-undang, dan peradilan administrasi, dan (2) konsep negara hukum (nle oflaw) berkembang di daratan amerika, khususnya "united states", dengan elemen-elemen: supremacy of law, equality before the law, the constitution based on individual rights atau due process of law. Konsep pertama mengembangkan wetmatig, rechtmatig dan doelmatig sebagai sarana atas "social service słate", sedangkan konsep kedua mengembangkan live, liberty dan property sebagai sarana atas "civil rights".

${ }^{4}$ Prinsip Demokrasi, diwujudkan dengan adanya: badan perwakilan rakyat, tidak ada jabatan seumur hidup, keterbukaan dalam pelaksanaan pemerintahan (openbaameid) dan peranserta masyarakat (inspraak), sedangkan asas instrumental diwujudkan dengan adanya prosedur birokrasi yang efisien (doelmatigheid) dan efektif (doeltraffendheid). 
sebagai suatu kekuasaan yang tidak terbatas. Kekuasaan bebas tetaplah merupakan kekuasaan yang tunduk pada hukum, yaitu berupa hukum tidak tertulis yang merupakan prinsip-prinsip pemerintahan yang layak ${ }^{5}$ sebagai landasan bagi pelaksanaan normanorma pemerintahan. Pada hakekatnya fungsi pemerintahan adalah untuk menjalankan proses birokrasi yang efisien dan efektif dalam melayani publik, kearah pewujudan masyarakat sipil yang semakin beradab.

\section{Perlindungan Terhadap Hak-hak Dasar}

Elemen kedua dari negara hukum adalah adanya pengakuan dan perlindungan hak-hak dasar (fundamental rights), sebagai ekspresi yuridis dari hak-hak (asasi) manusia (human rights) yang termuat dalam konstitusi negara. ${ }^{6}$ Dalam UUD 1945, bagian pembukaan alinea I dinyatakan bahwa kemerdekaan adalah hak dari segala bangsa, serta bagian pembukaan alinea IV dinyatakan bahwa kemanusiaan yang adil dan beradab. Demikian pula dalam batang tubuh UUD 1945, Pasal 27 mengakui adanya persamaan kedudukan setiap 'warga negara di dalam hukum dan pemerintahan serta persamaan hak atas pekerjaan dan penghidupan yang layak, Pasal 28 menjamin kemerdekaan untuk berserikat dan berkumpul serta mengeluarkan pikiran, Pasal 29 menjamin kemerdekaan untuk memeluk agama dan beribadat, Pasal 31 menjamin hak untuk mendapatkan pengajaran.

\section{Pembagian Kekuasaan Negara yang Jelas}

Pembagian kekuasaan negara sebagai jaminan tegaknya supremasi hukum dalam kehidupan kenegaraan, juga mérupakan suatu yang dipersyaratkan untuk dimưät dalam konstitusi negara. Gagasan peribáagiàn kekuasaan negara awalnya bersumbế dān gagasan pemisahan kekuasaan negara ke dalam berbagai organ, agar tidak berpusat. pada seorang sehingga dapat secara bebas menggunakan kekuasaannya untuk bertindak absolut, korup dan sewenang-wenang. Dua gagasan yang paling dikenal adalah teori pembedaan kekuasaan oleh John Locke dalam

sPhilipus Mandiri Hadjon. Agustus. 1993. Wet en Rechtmatig Bestuur. Yuridika. Him.4. “...principles of proper administration, atau algemene beginselen van behoorlik bestuur", yang dikenal selama ini adalah asas pertimbangan, asas kecermatan, asas kepastian hukum, asas kepercayaan atau asas menanggapi harapan yang telah ditimbulkan, asas persamaan, asas keseimbangan, asas kewenangan, asas fair play, larangan "detoumement de pouvoir, dan larangan bertindak sewenang-wenang.

${ }^{8}$ Konstitusi Tertulis, yang terbanyak pasalnya dimiliki negara India yang memuat $394 \mathrm{Pasal}$, serta yang terkecil jumlah pasalnya dimiliki negara Indonesia yang memuat 37 Pasal, selalu memiliki persamaan muatan utama, yaitu mengatur: (i) lembaga-lembaga negara dan wewenang-wewenangnya, serta (ii) perlindungan hak-hak (asasi) manusia. 
bukunya "Two Treaties of Govemmenf", serta teori pemisahan kekuasaan oleh Montesquieu dalam bukunya "L'esprit des Lois". .

Menurut Montesquieu, tegaknya suatu negara demokrasi memerlukan pemisahan kekuasaan negara ke dalam organ-organ eksekutif, legislatif dan yudikatif. Kekuasaan eksekutif bertugas melaksanakan undangundang, kekuasaan legislatif bertugas membuat undang-undang, serta kekuasaan yudikatif bertugas mengadili terhadap pelanggaran atas pelaksanaan Undangundang tersebut, sedang John Locke berpendapat bahwa untuk mencegah terjadinya kekuasaan yang melebihi batas harus dilakukan pembedaan pemegang kekuasaan dalam negara ke dalam kekuasaan eksekutif sebagai pelaksana Undang-undang, kekuasaan legislatif sebagai pembuat Undang-undang dan kekuasaan federatif untuk melakukan hubungan diplomatik dengan negara-negara lain.

Dalam realitas percaturan kehidupan kenegaraan di dunia, model pemisahan kekuasaan lebih banyak digunakan dengan berbagai modifikasi sesuai dengan relevansi kebutuhan di setiap negara dan sistem pemerintahan. Kekuasaan federatif sebagaimana dimaksudkan John Locke pada umumnya terintegrasi ke dalam kekuasaan eksekutif, yang diterjemahkan ke dalam "foreign policy institutions" atau "secretary state".

Pasal 1 ayat (2) UUD 1945, menyatakan bahwa negara indonesia menggunakan asas demokrasi atau kedaulatan rakyat, yaitu demokrasi perwakilan dengan sistem pemerintahan presidénsiil. Perjalanan sejarah kehidupan kenegaraan Indonesia telah memunculkan model pembagian kekuasaan sebagai berikut: [1]. Institusi demokrasi tertinggi adalah Majelis Permusyawaratan Rakyat (MPR). MPR merupakan penjelmaan seluruh rakyat dan memegang kedaulatan atas nama rakyat Indonesia, dengan keanggotaan yang berasal dari anggota $D P R$, utusan daerah dan utusan golongan. Kendatipun seluruh anggota MPR adalah wakil rakyat, namun MPR bukan Parlemen. DPR sesungguhnya lebih mencerminkan Parlemen, kendatipun anggotanya hanya sebagian dari anggota MPR. ${ }^{8}$ Negara demokrasi yang sistem pemerintahannya presidensil pada umumnya tidak bertanggung jawab kepada Parlemen, namun langsung kepada rakyat. Struktur demokrasi di Indonesia mengharuskan Presiden bertanggung jawab kepada MPR,

${ }^{7}$ Perbedaan utama antara kedua konsep tersebut adalah: (i) kekuasan eksekutif menurut Joh Locke merupakan merupakan kekuasaan yang mencakup kekuasaan yudikatif, karena mengadili berarti melaksanakan Undang-undang, sedangkan kekuasaan federatif yang berkaitan dengan hubungan luar negeri harus merupakan kekuasaan yang berdiri sendiri, serta (ii) menurut Motesquieu kekuasaan eksekutif sudah mencakup kekuasaan federatif, karena melakukan hubungan luar negeri merupakan salah satu wujud dari pelaksanaan Undangundang, sedangkan kekuasaan yudikatif haruslah bersifat terpisah dan mandiri dari kekuasaan eksekutif dan legislatif.

${ }^{8}$ Undang-undang No. 4 Tahun 1999 tentang Susunan dan Kedudukan MPR, DPR dan DPRD, Pasal 2 ayat (20) menyebutkan bahwa Jumlah anggota MPR adalah 700 orang, terdiri dari 500 orang anggota DPR, 135 orang Utusan Daerah, dan 65 orang Utusan Golongan. 
bukan kepada DPR atau langsung kepada rakyat pemilih. Keunikan struktur demokrasi Indonesia tercermin dari adanya hubungan politik yang kuat antara institusi Presiden, DPR dan MPR. [2].Institusi demokrasi di tingkat nasional yang menjadi poros kekuasaan tidak hanya tiga institusi, yaitu: eksekutif, legislatif dan yudikatif. Namun terdapat enam institusi, yaitu: MPR sebagai lembaga tertinggi, serta lima institusi tinggi lainnya di bawah MPR, terdiri dari DPR, Presiden, BPK, DPA dan MA, yang masing-masing berkedudukan sejajar. DPA berfungsi sebagai pemberi pertimbangan kepada Presiden, tetapi memiliki kedudukan yang sama dengan Presiden. Kekuasaan eksekutif dipegang Presiden dengan dibantu oleh para Menteri. Kekuasaan yudikatif dipegang oleh MA, namun dalam aspekaspek tertentu, seperti pemberian grasi, abolisi dan amnesti dipegang oleh Presiden. Kekuasaan legislatif dipegang oleh DPR bersama Presiden. Kekuasaan pengawasan penggunaan keuangan negara secara mandiri dipegang oleh BPK, yang umumnya kekuasaan ini dipegang oleh Parlemen atau MA. [3].Pemerintahan demokrasi di Indonesia menganut sistem presidensiil, namun hubungan antara ekskutif, legislatif dan yudikatif tidak menganut prinsip pemisahan kekuasaan, karena masing-masing institusi tersebut dapat saling berhubungan dan mempengaruhi secara langsung. Presiden memegang kekuasaan legislatif bersama DPR, Presiden memegang kekuasaan yudikatif tertentu bersama MA, MA melalui ketuanya mengambil sumpah para anggota DPR. Keunikan tersebut memang dimungkinkan karena adanya pengaturan struktural dalam UUD 1945.

\section{Badan Peradilan Administrasi}

Pasal 24 UUD 1945 menyatakan bahwa kekuasaan kehakiman dilakukan oleh Mahkamah Agung dan lain-lain badan kehakiman menurut undang-undang. Susunan dan kekuasaan badan-badan kehakiman itu diatur dengan undang-undang. Selanjutnya ketentuan Pasal 10 UU No. 14 Tahun 1970 membagi peradilan sebagai pemegang kekuasaan kehakiman ke dalam: (i) peradilan umum, (ii) peradilan agama, (iii) peradilan militer, dan (iv) peradilan administrasi atau disebut sebagai peradilan tata usaha negara. ${ }^{9}$ Keberadaan peradilan tata usaha negara pada hakikatnya mencerminkan ciri khas dari negara hukum (rechtsstaat). karena bermaksud sebagai institusi yang melakukan

9Philipus Mandiri Hadjon. "Fungsi Normatif Hukum Administrasi Dalam Mewujudkan Pemerintahan'Yang Bersihn. Dalam Pidato Penerimaan Jabatan Guru Besar Ilmu Hukum. tanggal 10 Oktober 1994. HIm.5. “...Istilah Peradilan Tata Usaha Negara digunakan dalam ketentuan Pasal 7 UU No. 19 Tahun 1964 tentang Ketentuan-ketentuan Pokok Kekuasaan Kehakiman (LNRI tahun 1964 No. 107, TLNRINo. 2699). Dalam penjelasan Pasal 7, khusus mengenai Peradilan Tata Usaha Negara dijelaskan: yang dimaksudkan dengan Peradilan Tata Usaha Negara adalah yang disebut "Peradilan Administrati" dalam Ketetapan MPRS No.IIMPRS/1960. 
kontrol hukum terhadap segala bentuk tindak pemerintahan yang tidak dijalankan berdasarkan hukum (rechtmatigheid van bestuur). ${ }^{10}$

Supremasi hukum yang merupakan ciriciri utama dari negara hukum merupakan suatu rumusan yang perlu dioperasionalkan agar dapat dilakukan proses penegakan hukum (law enforcement), baik dalam rangka penyelenggaraan pemerintahan yang stabil, bersih dan efisien maupun dalam rangka perlindungan hukum terhadap rakyat sebagai pemegang kedaulatan terhadap tindak pemerintahan yang bertentangan dengan hukum, sewenang-wenang dan mengandung penyalahgunaan wewenang. Proses tersebut harus dijalankan berdasarkan prinsip-prinsip demokrasi.

\section{Elemen-elemen Fundamental Demokrasi}

Elemen-elemen fundamental demokrasi diwujudkan dengan adanya: (i) badan perwakilan rakyat yang dipilih melalui sistem pemilihan umum yang langsung, bebas dan rahasia, (ii) tidak ada jabatan seumur hidup, (iii) keterbukaan dalam pelaksanaan pemerintahan dan (iv) peran serta masyarakat.

\section{Badan Perwakilan Rakyat}

Pemilihan umum (Pemilu) adalah instrumen penting dalam demokrasi, hal ini berkaitan dengan prasyarat mutlak adanya badan perwakilan rakyat yang sering disebut dengan istilah Partemen. Keanggotaan parlemen diisi melalui Pemilu, dimana seluruh rakyat diberikan kesempatan untuk memilih wakilwakil mereka di Parlemen untuk menggunakan wewenang-wewenang yang dimiliki untuk kepentingan rakyat yang diwakili. Setiap negara memiliki jumlah keanggotaan Parlemen yang berbeda, bergantung dari Undang-undang yang mengaturnya, dengan berdasarkan pertimbangan pada jumlah penduduk dan luas wilayah. Kendatipun dalam realitasnya terdapat anggota Parlemen yang ditunjuk," namun menurut sistem demokrasi atau setidaknya sebagian besar dari anggota Parlemen dipilih melalui Pemilu dengan sistem kepartaian. Artinya, rakyat memilih partai, selanjutnya partai sebagai peserta Pemilu mengumumkan identitas calonnya untuk menjadi anggota Parlemen.

Prinsip Pemilu yang dikenal, pada umumnya terdin dari: (i) satu daerah pemilihan memiliki seorang wakil (Single-member Constituency)

${ }^{10}$ Menurut Undang-undang No. 5 Tahun 1986 tentang PTUN Pasal 53 ayat (2) disebutkan bahwa ketidakabsahan suatu keputusan tata usaha negara (KTUN) sebagai bentuk tindakan hukum pemerintah disebabkan karena: a. KTUN tersebut bertentangan dengan peraturan perundang-undangan yang berlaku, $b$. Badan atau pejabat tata usaha negara pada waktu mengeluarkan KTUN tersebut telah menggunakan wewenangnya untuk tujuan lain dari maksud diberikannya wewenang tersebut, dan c. Badan atau pejabat tata usaha negara pada waktu mengeluarkan KTUN tersebut setelah mempertimbangkan semua kepentingan yang tersangkut dengan keputusan itu seharusnya tidakmengambil keputusan tersebut.

"Di samping adanya Penunjukan Anggota Badan Perwakilan di Indonesia dari Tentara Nasional Indonesia (TNI), anggota Majelis Tinggi (Senat) di Negara Kerajaan Inggris (menganut sistem demokrasi parlementer dengan bentuk negara monarkhi) dan Negara Kanada juga dilakukan dengan mekanisme penunjukan, bukan melalui Pemilu. 
yang dikenal pula dengan istilah sistem distrik, serta (ii) satu daerah pemilihan memiliki beberapa orang wakil (Multi-member Constituency) yang dikenal pula dengan istilah sistem perwakilan berimbang atau sistem proporsional.

\section{Sistem distrik}

Ditentukan berdasarkan kesatuan geografis. Setiap satuan geografis disebut distrik yang hanya memilih seorang wakil. Dalam hal ini, negara membagi wilayahnya kedalam satuan-satuan distrik yang jumlahnya sama dengan jumlah anggota Parlemen. Partai yang mendapat suara terbanyak dari setiap distrik calonnya berhak menduduki kursi Parlemen. Konsekuensi yang harus diterima partai yang kalah, maka di samping calonnya gagal menjadi anggota Parlemen, suara yang telah diperoleh menjadi terbuang. Sebagaimana suatu sistem hasil rumusan manusia, maka sistem distrik memiliki kelebihan dan kelemahan. Kelebihannya adalah: [1]. kecilnya batas distrik memungkinkan calon yang akan dipilih dapat dikenal dengan baik oleh rakyat pemilih; [2]. memotivasi partai politik untuk berintegrasi, karena kursi yang diperebutkan hanya satu untuk setiap distrik, sehingga untuk memperoleh suara dominan akan mendorong beberapa partai berintegrasi dalam satu partai; [3]. sederhana dan mudah dilaksanakan, serta berkurangnya partai mendorong terbentuknya pemerintahan yang stabil. Kelemahannya adalah: [1]. tidak memperhitungkan partaipartai kecil dan kelompok minoritas, terlebih jika partai-partai kecil dan kelompok minoritas tersebar dalam beberapa distrik. Kondisi demikian sangat menyulitkan partai kecil dan kelompok minoritas berhasil menjadikan wakilnya terpilih; [2]. tidak representatif, karena calon yang kalah pada suatu distrik kehilangan suara pendukungnya, sehingga mereka tidak memiliki wakil di Parlemen.

\section{Sistem Proporsional}

Ditentukan kapasitas kursi yang diperoleh suatu partai sesuai dengan kapasitas suara yang diperoleh. Dalam sistem tersebut seluruh wilayah negara dibagi ke dalam daerah-daerah pemilihan, yang luas daerahnya jauh lebih luas dari luasnya distrik dalam suatu sistem distrik. Dengan demikian setiap suara dihitung secara keseluruhan sehingga tidak ada yang hilang, dalam hal suara dari jatah kursi di satu daerah pemilihan dapat dikompensasikan dengan terjadinya kelebihan suara di daerah lain, atau model penggabungan suara yang lainnya sesuai dengan peraturan pemilu yang disepakati. Sistem proporsional umumnya dikombinasikan dengan sistem daftar di mana rakyat pemilih memilih salah satu partai yang telah membuat daftar calon anggota parlemen yang disusun berdasarkan peringkat tertentu. Kelebihannya adalah; [1]. tidak ada suara yang hilang serta komposisi keanggotaan parlemen lebih mencerminkan komposisi dari suara rakyat pemilih; [2]. partai-partai kecil dan kelompok minoritas mendapatkan tempat yang relatif memadai dalam proses pemilihan serta memiliki peluang untuk menempatkan wakilnya di parlemen. Kelemahannya adalah [1]. sangat mudah terjadi fragmentasi dan mendorong timbulnya partai-partai baru, serta mempersulit proses integrasi partai karena stabilitas partai sangat ditentukan tendensi emosionalitas dan heterogenitas dalam masyarakat; [2]: keterikatan anggota parlemen pada partai membawa konsekuensi loyalitas yang. lebih dominan kepada partai dibandingkan dengan loyalitas mereka pada rakyat pemilih; [3]. kualitas anggota parlemen 
tidak bersifat personifikatif dan tidak mencerminkan kemampuan individual semata-mata; [4]. kecenderungan tumbuhnya banyak partai mempersulit terbentuknya pemerintahan yang.stabil kecuali ada koalisi yang kuat antar partai.

Menurut Undang-undang No. 2 Tahun 1999 tentang Partai Politik dijelaskan bahwa partai politik berfungsi untuk: a. melaksanakan pendidikan politik dengan menumbuhkan dan mengembangkan kesadaran atas hak dan kewajiban politik rakyat dalam kehidupan berbangsa dan bernegara; b. menyerap, menyalurkan dan memperjuangkan kepentingan masyarakat dalam pembuatan kebijakan negara melalui mekanisme badan perwakilan rakyat; c. mempersiapkan anggota masyarakat mengisi jabatan-jabatan politik sesuai dengan mekanisme demokrasi, serta sebagai lembaga demokrasi merupakan wahana guna menyatakan dukungan dan tuntutan dalam proses berpolitik (Pasal 7 ayat [1] dan [2]).

Untuk melaksanakan fungsi tersebut partai politik mempunyai hak ikut serta dalam pemilu sesuai dengan undang-undang serta memperoleh perlakuan yang sama, sederajat dan adil dari negara (Pasal 8). Dalam UU No. 3 Tahun 1999 tentang Pemilu dinyatakan bahwa pemilu adalah sarana pelaksanaan kedaulatan rakyat dalam Negara Kesatuan Republik Indonesia berdasarkan Pancasila dan UUD 1945 serta dilaksanakan untuk memilih anggota DPR, DPRD I, DPRD II kecuali keanggotaan badan perwakilan dari $\mathrm{TNI}$, dilaksanakan dengan menggunakan sistem proporsional berdasarkan stelsel daftar (Pasal 1 ayat 1,4 dan 7$)^{12}$

\section{Tidak Ada Jabatan Seumur Hidup}

Pembedaan utama antara sistem negara monarchi yang bersifat tradisional serta sistem negara demokrasi yang modern adalah adanya pembatasan masa jabatan pada para pemegang kekuasaan. Dengan demikian sistem negara demokrasi harus ada pembatasan masa jabatan. UUD 1945 Pasal 7 menyatakan bahwa Presiden dan Wakil Presiden memegang jabatannya selama masa lima tahun dan sesudahnya dapat dipilih. kembali, dengan keterangan dalam bagian penjelasan dinyatakan cukup jelas.

Dalam proses politik sepanjang sejarah perjalanan bangsa Indonesia, ternyata ketentuan yang memuat norma tersamar (vague normen) tersebut telah memberikan peluang kepada Presiden yang memang memiliki kekuasaan yang besar dibandingkan lembaga tinggi negara lainnya, untuk melakukan penafsiran yang bertentangan dengan prinsip demokrasi dalam penyelenggaraan pemerintahan negara.

Sebab ketentuan tersebut menumbuhkan praktik seorang Presiden yang sama dipilih secara terus menerus tanpa adanya proses

12Undang-undang No. 2 Tahun 1999, mengandung beberapa norma demokrasi seperti peserta Pemilu yang mencerminkan realitas kemajemukan (diversity) rakyat dalam kapasitas, perlakuan dan fungsi yang sejajar (equally) dan tidak dilibatkannya elemen birokrasi ke dalam proses verifikasi dan seleksi peserta dan hanya menggunakan birokrasi dalam proses pelayanan teknis administrasif dan penegakan hukum. 
hukum yang dapat mencegahnya. Oleh karena itu sudah semestinya dikembangkan suatu wacana dalam konteks pendidikan politik guna mendorong perlunya suatu undangundang tentang lembaga kepresidenan yang memuat antara lain: Presiden dipilih oleh dan bertanggung jawab langsung kepada rakyat, Presiden adalah warga negara Indonesia asli (natural bom citizen), masa jabatan Presiden (termasuk Wakil Presiden) paling lama dua kali masa jabatan berturut-turut, pembatasan kekuasaan mengesahkan atau menolak RUU yang telah disetujui DPR, DPA wajib memberikan pertimbangan kepada Presiden atas RUU yang diajukan kepada DPR. DPA wajib memberikan penilaian pendahuluan terhadap pemerintah dan lain-lain.

\section{Keterbukaan dalam Pelaksanaan}

\section{Pemerintahan}

Prinsip keterbukaan merupakan elemen penting dalam penyelenggaraan pemerintahan modem, yang berorientasi pada konsep negàra kesejahteraan yang bertumpu pada kekuatan masyarakat sipil, dengan bercirikan birokrasi yang efisien, efektif, impersonal, impartial, objektif, rasional dan berorientasi pada kepentingan publik. ${ }^{13}$ Prinsip keterbukaan membawa konsekuensi adanya kewajiban pemerintah untuk secara proaktif memberikan informasi kepada masyarakat, serta menjelaskan kepada masyarakat atas berbagai hal yang dibutuhkan. Pelaksanaan prinsip keterbukaan membawa konsekuensi perlunya pelaksanaan prinsip peranserta masyarakat, melalui berbagai sarana, seperti sarana keberatan, sarana dengar pendapat, komisi pertimbangan, komisi investigasi, advisory dan supervisi, dan lain-lain.

\section{Peran Serta Masyarakat}

Prinsip peran serta masyarakat (public participation) ${ }^{14}$ merupakan elemen penting dalam proses pelaksanaan demokrasi, maknanya memberikan peluang adanya peran serta aktif masyarakat dalam proses pengambilan keputusan, khususnya kelompok yang terkena dampak langsung suatu kegiatan pembangunan sebagai akibat dari kebijaksanaan publik (public policy). Pelaksanaan prinsip peran serta masyarakat bertujuan untuk: (i) melahirkan prinsip kecermatan dan kehati-hatian dari pejabat publik dalam membuat kebijaksanaan publik, (ii) membawa konsekuensi munculnya suatu kontrol sosial yang konstruktif dan kesiapan. sosial masyarakat terhadap setiap bentuk dampak akibat suatu kegiatan pembangunan.

\footnotetext{
${ }^{13}$ Kebijaksanaan publik yang tepat dari pemërintah akan membawa dampak positif berupa: menguatnya legitimasi, kejelasan dalam memberikan interpretasi peraturan yang berlaku, ketidakraguan dalam memberikan sanksi dan memperkuat integritas kepemimpinan.

"P. de Haan cs. "Hukum Administrasi", terjemahan oleh Philipus M. Hadjon et.al. Him.28. Menjelaskan bahwa ruang lingkup kajilan hukum administrasi (negara) adalah mengatur sarana penguasa dalam mengendalikan masyarakat, cara partisipasi mäsyarakat dalam pengambilan keputusan, perlindungan hukum dan penetapan norma fundamental dalam pemenintahan.
} 


\section{Perlunya Wakil Rakyat Menguasai Pengelolaan Konflik Sosial}

Dalamimendorong proses demokrasi, khususnya tèrhadap terlaksananya prinsip keterbukaan pemerintah dan prinsip peran serta masyarakat, maka perlu diantisipasi munculnya suatu konflik sosial yang destruktif, serta sekaligus dapat memelihara suasana kompetitif dan dinamis dalam kehidupan masyarakat, sebagai suatu energi kehidupan. ${ }^{15}$

Dengan demikian, untuk memotivasi terbangunnya proses peran serta masyarakat tersebut, setiap anggota badan perwakilan, selaras dengan salah satu fungsinya untuk menampung dan menindaklanjuti aspirasi masyarakat, ${ }^{16}$ sudah semestinya memahami pentingnya metode pendekatan dalam pengelolaan konflik dalam masyarakat secara tepat. Hal ini, menjadi semakin penting, karena selama ini pendekatan dalam pengelolaan.: konflik melalui: (i) pendekatan kekuasaan; seperti menyelesaikan konflik dengan cara militer, kekerasan sipil, kekerasan ekonomi (suap, korupsi, dan lain-lain), cara kekerasan lainnya, dan (ii) pendekatan represi hukum melalui lembaga peradilan, yang hanya memberikan pilihan adanya pihak yang dinyatakan menang atau kalah, menjadi model yang dominan. ${ }^{17}$

Realitas sosial memperlihatkan, bahwa penggunaan pendekatan yang tidak tepat dalam pengelolaan konflik selama ini, mengakibatkan: (i) tidak pernah menyelesaikan akar persoalan (kepentingan sebagai penyebab terjadinya) konflik, sehingga lembaga pengelolaan konflik (pemerintah) menjadi kurang percaya diri, serta (ii) sistem hukum yang diproduk cenderung memihak pemerintah dan justru menjadi tidak melindungi rakyat, serta munculnya rasa tidak berdaya untuk mengambil langkah konstruktif dalam pengelolaan konflik dengan cara menggali dan mempertemukan nilai, kebutuhan dan kepentingan para "stakeholders". Kondisi demikian, jelas mengakibatkan lemahnya partisipasi masyarakat sebagai prasyarat penting bagi proses demokrasi yang sehat.

Ruang penyebab terjadinya konflik masyarakat, pada dasarnya terbagi kedalam dua kategori, yaitu: (i) konflik data, yang disebabkan oleh kekurangan informasi yang

${ }^{15}$ Konflik inheren dengan hidup dan kehidupan manusia. Konfilik dapat derajat tertentu (rasional dan bermoral) sangat dibutuhkan untuk mendorong terwujudnya kompetisi kehidupan yang beradab. Namun, dalam eskalasi yang tidak dapat dikendalikan, konflik justru menjadi ancaman bagi terwujudnya kompetisi kehidupan yang beradab. Mampu menjerumuskan manusia dalam pola kehidupan biadab.

${ }^{18}$ Undang-undang No. 4 Tahun 1999 dalam pasal 34 ayat (2) menjelaskan bahwa DPRD memiliki tugas dan wewenang: memilih eksekutif daerah, mengusulkan pengangkatan dan pemberhentian eksekutif daerah kepada Presiden, bersama eksekutif daerah menetapkan APBD, bersama eksekutif daerah membentuk Perda, memberikan pendapat kepada pemerintah pusat atas perjanjian internasional yang menyangkut daerah, serta menampung.

${ }^{17}$ Dalam proses politik maupun proses sosial di Indonesia, penggunaan metode resolusi konflik yang dilakukan berdasarkan keragaman kepentingan dan mengedepankan prinsip kemanusiaan tanpamengabaikan prinsip kepastian hukum, masih belum banyak dilakukan. 
dibutuhkan untuk pengambilan keputusan secara bijaksana, mendapatkan informasi secara salah, tidak adanya kesepakatan mengenai apa saja data yang dianggap relevan, menerjemahkan informasi dengan cara yang berbeda; serta (ii) konflik kepentingan, yang disebabkan oleh persaingan kepentingan yang dirasakan atau memang secara nyata (faktanya) tidak bersesuaian. Dalam konteks ini, konflik terjadi ketika suatu pihak meyakini bahwa untuk memuaskan kebutuhannya harus mengorbankan pihak lain. Konflik tersebut bersumber pada masalah substansi seperti sumber daya manusia, sumber daya alam, model penerapan hukum, pengendalian nilai tukar mata uang, dan lain-lain. ${ }^{18}$

Realitas sumber konflik di Indonesia, pada umumnya terjadi oleh dua aspek, yaitu: (i) ekonomi, dicirikan dengan adanya kegiatan pembangunan (kesehatan, makanan, pendidikan) yang tidak menjangkau seluruh elemen masyarakat, menajamnya gap antara kaya dan miskin (enclave di Timika, Lhokseumawe, kota-kota di Jawa, dan lainlain), eksploitasi SDA (hutan, tambang) yang dipergunakan untuk penguasa dan kroninya, serta (ii) politik, dicirikan oleh adanya regime yang berpola "raja dan hamba", regime yang korup, diskriminasi dalam proses politik, peniadaan kontrol dan partisipasi publik, represi militer untuk setiap penyelesaian konflik, tidak diterapkannya hukum dan praktik demokrasi yang bermartabat.
Pengelolaan konflik yang dilakukan secara tepat, memiliki implikasi positif, berupa: (i) dari aspek proses lebih hemat dilihat dari biaya ekonomi dan biaya sosial, dibandingkan proses pengelolaan litigasi dan proses lainnya, serta (ii) menciptakan sikap proaktif secara wajar dari berbagai pihak untuk mencapai kesepakatan, (iii) menghindarkan munculnya kekerasan yang dapat memicu terjadinya tragedi sosial dan kemanusiaan yang mahal, (iv) memberikan kemungkinan peluang bagi para pihak untuk saling memahami kesamaan dan perbedaan kepentingan di antara mereka.

Hal ini berarti bahwa pengelolaan konflik yang teragenda jelas dan sistematis memberikan proses pendewasaan untuk memahami realitas dan substansi masalah. Beberapa agenda utama yang perlu dikedepankan sebagai prinsip dalam pengelolaan konflik, adalah sebagai berikut: [1]. kriteria pengelola; [a]. memahami secara jelas faktor-faktor yang menjadi akar masalah (dapat memberi kontribusi konflik dan solusinya); [b]. bersikap otonom, profesional dan non-partisan; [c]. bersikap netral, tetapi memiliki komitmen terhadap perbaikan masa depan bersama; [d]. demokratis, setiap aktor diberi kesempatan yang setara dan memadaj dalam proses pengambilan keputusan. [2]. Tahapan pengelolaan; [a]. mengidentifikasi indikator-indikator dari konflik yang ada, [b]. Identifikasi para aktor yang terlibat dalam konflik; [c]. menganalisis kecenderungan-

\footnotetext{
${ }^{18}$ Sebab konfiik umumnya didasarkan pada: 1 . Adanya kesenjangan dalam hubungan antarmanusia seperti faktor emosi-emosi yang labil, salah persepsi (stereotip), sikap negatif(aprioni), atau salah pengertian; 2. Perbedaan nilai: nilai sehari-hari, nilai tetap, atau masalah definisi nilai; 3. Perbedaan data: kurang informasi, perbedaan pandangan, perbedaan interpretasi; 4. Masalah struktural: sumber daya dan kekuasaan pengambilan keputusan; dan 5. dan Kepentingan: substantif atau tatacara.
} 
kecenderungan dan skenario-skenario yang dapat dilakukan untuk pemetaan dan penentuan alokasi kebutuhan (conflict transformation); menggali (explore) perbedaan dan pesamaan berkaitan dengan nilai, kebutuhan dan kepentingan para aktor; membangun visi dan misi bersama; membangun persepsi tentang akar masalah dari para aktor; melakukan "cross perception" dari hasil persepsi para aktor; [d]. mengambil simpulan sementara untuk landasan kebijakan yang direkomendasi untuk para aktor yang dapat diklasifikasikan sebagai "stakeholders"; [e]. merumusan resolusi konflik bersama para aktor.

\section{Simpulan}

Penyelenggaraan pemerintahan yang bertumpu pada prinsip kedaulatan rakyat mutlak memerlukan penegakan supremasi hukum dan kejelasan mekanisme demokrasi. Penegakan supremasi hukum sangat bergantung pada ketajaman dan kecermatan kinerja pengaturan hukum dan peraturan perundang-undangan untuk lembaga pemerintahan, lambaga perwakilan dan lembaga peradilan, serta jaminan perlindungan hukum individu [warga negara] terhadap perilaku kekuasaan dan perilaku sosial yang melanggar norma hukum.

Demikian pula, pilihan sistem dan mekanisme demokrasi oleh rakyat dalam memilih para pejabat pemerintahan dan para anggota perwakilan, harus dilakukan melalui penegakan supremasi hukum.
Dalam praktik penegakan supremasi hukum dan pelaksanaan demokrasi, pada umumnya aspek kultural sering tertinggal atau sering tidak serasi dengan kualitas aspek substansi. Ketidakserasian aspek struktural dan internal dalam manjalankan demokrasi dan penegakan supremasi hukum dapat berdampak pada meletup dan berkembangnya konflik politik dan sosial yang kontra produktif. Diperlukan kemampuan melakukan manajemen konflik bagi para wakil rakyat sehingga lembaga politik diperlukan agar konflik dalam masyarakat dapat berfungsi sebagai energi yang dinamis untuk pendewasaan kehidupan demokrasi melalui penegakan hukum yang konsisten. $\square$

\section{Daftar Pustaka}

Gani, Abdul. dalam Padmo Wahjono. 1985. Masalah Ketatanegaraan Indonesia Dewasa Ini. Indonesia: Ghalia.

Haan, P. de., cs. "Hukum Administrasi". Terjemahan oleh Philipus M. Hadjon et.al.

Hadjon, Philipus Mandiri. Agustus 1993.Wet en Rechtmatig Bestuur. Yuridika.

. "Fungsi Normatif Hukum Administrasi dalam Mewujudkan Pemerintahan yang Bersih." Pidato Penerimaan Jabatan Guru Besar IImu Hukum. Tanggal 10 Oktober 1994.

Lonergan, Bernard "Dialectic of Authority." Dalam Frederick J. Adelmann. 1984. Authority. Martinus Nijhof. The Hague. 